\title{
Mediation sought on biotechnology disputes
}

San Francisco. The biotechnology industry, confronted with indications that genetically engineered foods face a wary or even hostile public, has enlisted a mediation team to help it find common ground with its critics.

The first genetically engineered whole food, a tomato made by Calgene Inc., is likely to reach grocery store shelves later this year (see Nature 357, 352; 1992). But already chefs are vowing not to serve it, farmers are agreeing not to grow it and consumers are asking how it and other biotech foods will be labelled. Earlier this month, Campbell Soups announced that it had no plans to sell any product containing the tomato, which it helped to develop.

The Industrial Biotechnology Association has asked Resolve, a centre for environmental dispute resolution in Washington, to see whether its opponents would be willing to talk face-to-face. "We were hoping that it might create a forum that would allow discourse at a slightly lower volume", says Richard Godown, president of the Washington-based trade association.

The association is concerned that the public might not accept the new products because of concern about the way the government regulates them. Last year, the US Food and Drug Administration (FDA) said that genetically engineered foods would not require any special labelling or safety testing unless there were indications that they might cause allergic reactions or pose safety concerns.

Environmental groups, convinced that the foods should be labelled, tested for safety and registered, urged their members to write to the FDA. Jeremy Rifkin, an outspoken industry critic, began organizing a boycott

\section{US keeps promise on biodiversity}

Washington. Outgoing President George Bush this week was expected to sign an executive order creating a National Biodiversity Center to serve as a repository for scientific data on biodiversity within the United States and its territories. The order, coming in the final days of an administration with a reputation for dragging its feet on environmental issues, directs the Smithsonian Institution to take the lead in working out an agreement among federal agencies to establish and fund such a centre.

At present the US government has no clearinghouse for biodiversity information. Taxonomic and other data on species, habitats and ecosystems exist in many places, including museums, universities, government agencies and conservation groups. In its simplest form the new centre would set up an electronic network linking the different databases; a more elaborate plan would be a single large database at a location yet to be determined.

The executive order designates a committee of at least a dozen federal agencies to determine the scope and structure of the new centre, which could be in operation within a year.

The centre is not expected to require the construction of a new facility. It would neither collect data nor do biological surveys. "There's a strong argument for keeping the science separate from the policy", says Thomas Lovejoy, assistant secretary for external affairs at the Smithsonian and a leading figure in negotiations to create the centre.

In fact, one reason the Smithsonian was selected is its reputation as a nonpartisan research agency. "Biodiversity is still a politically touchy issue, and they [the White House] wanted to put the centre somewhere with the least possible political content", says Peter Jutro, who heads the biodiversity research programme at the Environmental Protection Agency.

Both the centre and an international workshop on biological surveys held last week in Washington fulfil promises made by the Bush administration during the environmental summit held last summer in Rio de Janeiro. Although the United States did not sign the convention on biological diversity at the summit, it endorsed the idea of establishing centres to coordinate scientific data-gathering within individual countries and offered to host the first international workshop to set standards for coordinating biological surveys.

White House officials wanted to hold the workshop, involving scientists and administrators from several US government agencies as well as representatives from 12 other countries, before the end of Bush's term of office on Wednesday this week. Its recommendations will go to the United Nations Environment Programme and to other organizations working on biodiversity issues.

Participants at the workshop were concerned that museums and private institutions might be reluctant to share their data, particularly with commercial interests that might use them for profit. "Some of the best experience in this area is in private zoos, herbariums and organizations like the Nature Conservancy", says Jutro. "We have to have a big tent."

Although Bush was expected to sign the order creating the centre before leaving office on 20 January, Clinton also supports the idea, says Jutro. "I think it will be followed up enthusiastically by the next administration."

Tony Reichhardt and signed up thousands of chefs, growers and distributors.

The FDA has received 3,200 comments on its proposed regulations. About 85 per cent have asked that all genetically engineered foods be labelled, with 50 per cent also requesting premarket testing to prove safety. Food allergies were the concern of 40 per cent, while 10 per cent raised ethical or religious issues. The FDA is considering an open meeting to talk about the labelling question and is meeting experts on food allergies, said James Maryanski, biotechnology coordinator for the agency's Center for Food Safety and Applied Nutrition.

FDA officials also have agreed to an initial meeting with Resolve, which is contacting environmental groups such as the Environmental Defense Fund and the National Wildlife Federation. Rifkin has not been approached. Calgene is also a participant.

Resolve, a subsidiary of the World Wildlife Fund, helped to bring about the National Wetlands Policy Forum that led to a government policy stipulating no net loss of wetlands. For five years, it has conducted a quarterly roundtable meeting on the ecological effects of pesticides with representatives from government, industry, universities and the environmental movement.

The organization typically convenes a group of about 20 people holding diverse views on a particular issue and tries to reach a consensus. The result can be policy recommendations, agreements on joint research or even a draft of new federal rules. In the case of genetically engineered foods, new regulations would not be possible because the FDA did not initiate the process.

Resolve expects to complete a feasibility study within a couple of months to decide whether the project should proceed, what its goals would be and who would fund it. Potential participants are optimistic.

Sally Lehrman

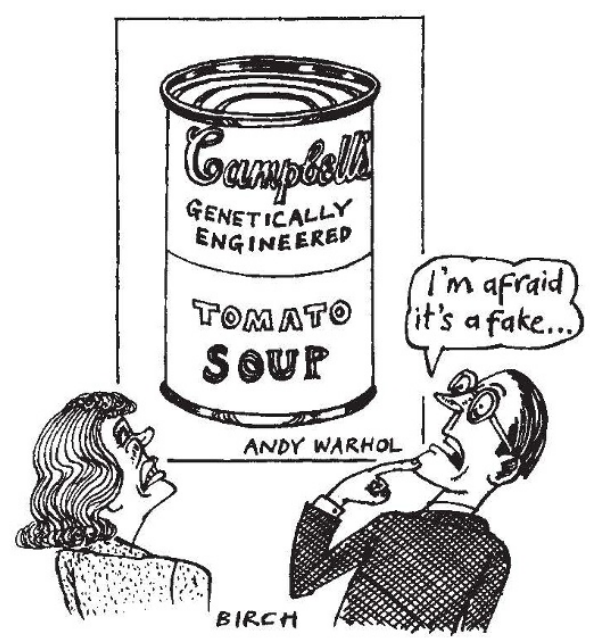

